\title{
Geoarchaeology of La Tène Sunken Houses at Syrovice, Czech Republic: Importance for Understanding Living Strategies
}

\author{
David Parma ${ }^{\mathrm{a}}$, Lenka Lisá ${ }^{b^{*}}$, Markéta Jarošovác, Libor Petr ${ }^{\mathrm{b}}$ \\ aInstitute of Archaeological Heritage Brno, Kaloudova 30, 60200 Brno, Czech Republic \\ ${ }^{b}$ Institute of Geology AS CR, v. v. i., Rozvojová 269, Prague 6, 165 00, Czech Republic \\ 'Department of Geological Sciences MU Brno, Kotlářská 2, 61137 Brno, Czech Republic
}

\section{ARTICLE INFO}

\section{Article history:}

Received: 17 May 2011

Accepted: 10 August 2011

\section{Key words:}

polycultural site

sunken houses

La Tène period

Roman period

Geoarchaeology

micromorphology

\begin{abstract}
$A B S T R A C T$
A polycultural settlement site was found at Syrovice near Brno, Czech Republic, during a rescue survey in 2008. Within a widespread cultural layer 100 sunken features were excavated and dated to the La Tène and Roman periods. Given their characteristic shape and infill, several features were interpreted as typical sunken houses. The way the houses were used was identified from the abundant artefacts, and sedimentological and micromorphological analysis.
\end{abstract}

\section{Introduction}

The authors would like to introduce the polycultural site of Syrovice near the city of Brno in southern Moravia and to illustrate how a geoarchaeological approach can shed new light on living strategies, which are currently largely deduced only from the remains of architectonical features or from artefacts spread within the cultural layer or infill of investigated contexts. Despite the fact that polycultural localities of this type are quite common in southern Moravia, there are no reported interpretations based directly on the study of the infill of La Tène or Roman period sunken houses, until this study. To date, the only reported La Tène period site where the microstratigraphy of the sediment in a sunken house has been studied is at Tuněchody near Hradec Králové, in northern Moravia (Tichý et al. 2011).

Sunken houses are found in different cultures worldwide. In recent years pit-houses, also known regionally as Grubenhäusers or sunken houses, have moved increasingly

*Corresponding author. E-mail: lisa@gli.cas.cz into the focus of attention. In contrast to many archaeological features the infill of sunken houses and floor layers often survive. Important archaeological information about the construction, use and abandonment of sunken houses, along with the local landscape and soil management, may be preserved within the infill. Sunken houses are a common architectonical feature from the Late Bronze to the Roman period (Venclová ed. 2008); Europe is rich with La Tène period sunken houses though their frequency decreases moving westward (Venclová ed. 2008). Only eight La Tène period sunken houses, for example, were found at the large and well-excavated Manching opidium in Bavaria (Sievers 2000).

In the last few years the study of La Tène period sunken houses within the Czech Republic has been largely conducted by Meduna (1980), Waldhauser (1993), Rybová and Drda (1994). Finds from the infill of sunken houses have been technically examined largely by Meduna (1980), who devised a detailed typological classification system based on ground plans and the number of preserved postholes. This classification is based on a set of older finds documented in the Czech Republic up to the 1970's. Meduna (1980) 
generally interpreted La Tène sunken houses as farming purposed. His main arguments relying on the relatively small proportion of sunken houses, the absence of heating facilities, and the known parallel existence of large aboveground wooden buildings. Those buildings are considered to be primarily dwellings, as demonstrated at the site at Staré Hradisko (Meduna 1980).

The expansion of large rescue excavations in the last decades of the $20^{\text {th }}$ century uncovered a large number of La Tène period sunken houses in Moravia, including entire settlements. Urban questions linked to construction strategies have been described and interpreted by Čižmář (2003) from the site at Bořitov. But the purpose of sunken houses remained unanswered. Practically none of the larger excavations of the last few decades within Moravia were fully compiled or properly published as, for example, Brno - Turrany or Medlovice. Despite the fact that these sites have been excavated the absence of published data prevents us from evaluating the function of sunken houses, at least from the point of view of the basic spatial relations of settlements units. Meduna's initial thesis that "the function of sunken La Tène houses cannot be explicitly determined" remains unchanged (Meduna 1980). The thesis, as well as the way that sunken houses are usually excavated (usually just the exploration of infilling, finds collection, documentation and archaeobotany sampling), also remained unchanged. Usually mechanical stripping devastates the preserved remains of superposed layers including possible cultural layers and the original surface of the settlement. On the other hand these horizons are usually already devastated by ploughing and erosion. A number of excavations of La Tène period sites with preserved cultural layers remain unpublished (e.g. Sudoměřice, Višňové or Medlovice). Studies focused on the question of the function of La Tène period sunken houses based on an analysis of direct evidence of their usage that is on the study of floor horizons, are practically non-existent. New possibilities for analysis, based on a more precise excavation technique of prehistoric cultural layers, have been suggested by Ernée (2008).

In recent decades geoarchaeology has become a very important interdisciplinary approach in archaeological studies (Courty, Goldberg, Macphail 1989; Macphail, Cruise 2001; Goldberg et al. 2001; French 2003; Goldberg, Macphail 2006). Micromorphology in archaeological contexts has become a commonly used method to detail the processes of site development (Goldberg, Macphail 2006; French 2003). The identification of floor layers has been successfully used in different archaeological periods and regions, such the Neolithic (Karkanas, Efstratiou 2009; Boivin 2000), Early Iron Age (Jarošová et al. 2010), urban sites in the Near East (Matthews et al. 1997) and the Medieval period (Milek 1997; Kuna et al. 2011; Lisá et al. 2008).

Within the Czech Republic the micromorphological approach in archaeological contexts was successfully used to interpret the environmental history of Svobody Square in Brno (Lisá et al. 2007), the reconstruction of the infill of Hallstatt sunken houses near Modřice (Jarošová et al. 2010) and the investigation of floor layers of a Medieval cellar (Lisa et al. 2008)

\section{Geographical context}

The site at Syrovice is located on the western slopes of the Dyjskosvratecký valley (Fig. 1), approximately 15 kilometres south of Brno, on the southern edge of the village of Syrovice. The area of the site is demarcated by the Syrovice to Sobotovice road to the east, the village to the north, and an unnamed seasonal stream to the south and southwest. The site itself is situated on very gentle eastern slope in close proximity to the Syrůvka Creek, at the altitude of $220 \mathrm{~m}$ above mean sea level (AMSL). GPS coordinates of the site are $49^{\circ} 4^{\prime} 27.022^{\prime \prime} \mathrm{N}$ and $16^{\circ} 32^{\prime} 54.453^{\prime \prime} \mathrm{E}$. The geological background is composed of Tertiary Neogene marine deposits covered by Quaternary Wechselian loess, the most common Quaternary deposits within the area of Dyjskosvratecký valley (Lisá et al 2005). Due to water and slope erosion of loess deposits at the bottom of the Syrůvka Creek valley, Neogene sands and gravels have been exposed there. The site itself is located on loess with a Chernozem soil cover.

\section{Archaeological context}

The number of archaeological sites found in the Syrovice area is quite high. They are usually found close to the $19^{\text {th }}$ century brickyards situated in the village, such as the sites found within the former Kelbl brickyard. A set of surface finds of the so called "tumulus culture" (the former designation for the Hallstadt period) was documented in the Kelbl brickyard at the beginning of $20^{\text {th }}$ century. $\mathrm{K}$ Procházka excavated a pit with Roman period finds in 1908, and surface finds from the field above the brickyard, dated to the Roman period, are reported by H. Freising (Belcredi et al. 1989). Most of the area around the former Kelbl brickyard was recently built up. Another link between Syrovice and former finds can be found in Freising's report, where he notes finding La Tène settlement on the "gentle low hill on the right bank of the stream, southeast of the village". Other La Tène finds are reported from the more remote A. Janek and Niva brickyards. Their context is more of a burial. No other Roman or La Tène period sites were reported from the area (Belcredi et al. 1989).

\section{Methodology}

The excavation started with minimal surface stripping to a depth of $20-30 \mathrm{~cm}$, but was stopped when clearly visible cultural layers appeared. The eastern part of the site was also examined, and handmade cuts demonstrated the presence of cultural layers of variable thickness.

Ceramic finds coming from the infill of La Tène period sunken houses were described using a single-purpose 


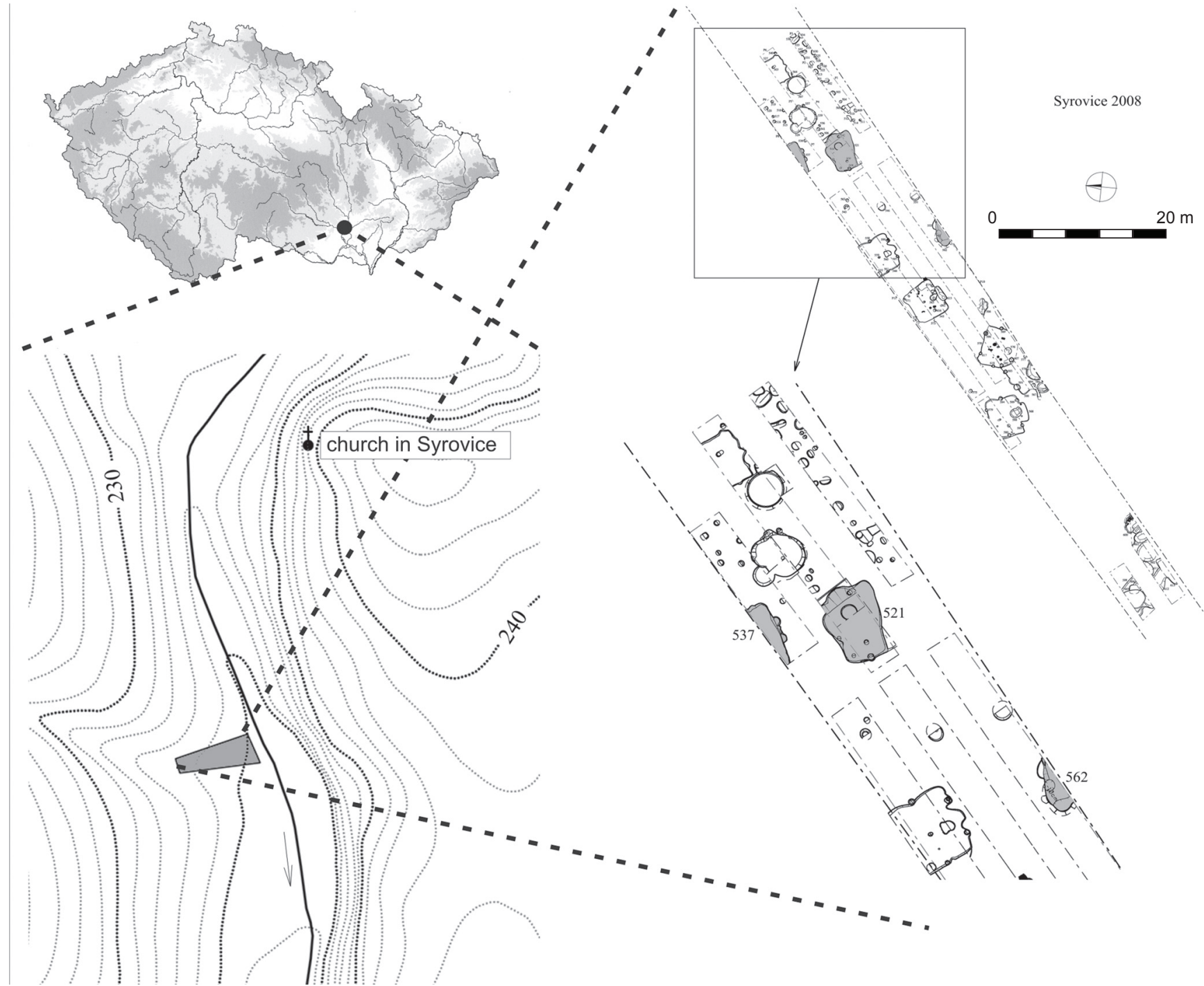

Figure 1. The geomorphological position of Syrovice site near Brno, Czech Republic.

database (Parma 2011). The evidence included the number of vessels, the number of fragments which were reconstructed into their original vessels, the net weight of ceramic sherds, their category, and compiled data about the size and type of fragments. One data element included types of ceramics with similar features coming from the same context. The descriptions within the ceramic database are based on the classification methodology of Macháček (2001). Technically the database is based on the design developed by Šabatová (Šabatová, Vitula 2002).

Three sets of micromorphological samples were taken from the bottom of the infill of two La Tène sunken houses, and one from the floor layer of a sunken house dated to the Roman period. Samples were held in plastic Kubiena boxes $(5 \times 9 \mathrm{~cm})$ and prepared according to standard procedure $(i . e$. drying, impregnation and thin sectioning, as per Bullock et al. 1983; 1985; Murphy 1986; Stoops 2003). Thin sections were studied under a binocular and polarising microscope in different magnifications and described according to Bullock et al. 1983; 1985; Stoops 2003; Stoops et al. 2010.
Phytoliths were observed in the thin sections at 200× magnification. This method is useful (Piperno 2006), but less suitable than flotation using heavy liquids (Lentfer, Boyd 1998). The weakness of this method is that individual phytolith bodies are less visible and therefore their identification is more difficult. Phytolith terminology is based on Madella et al. 2005.

\section{Results}

\subsection{General characteristics of the site}

The excavated area has a more or less linear character (Figure 1), with a length of $134 \mathrm{~m}$ and a width varying between 7.5 to $10.5 \mathrm{~m}$. Within this area 119 sunken objects were documented. Most are concentrated in the north-eastern part of the excavated area, and dated to the La Tène and Roman periods. The remainder of the archaeological finds are concentrated in the south-western part of the excavated area and dated to the early Medieval period. The most common objects and finds 


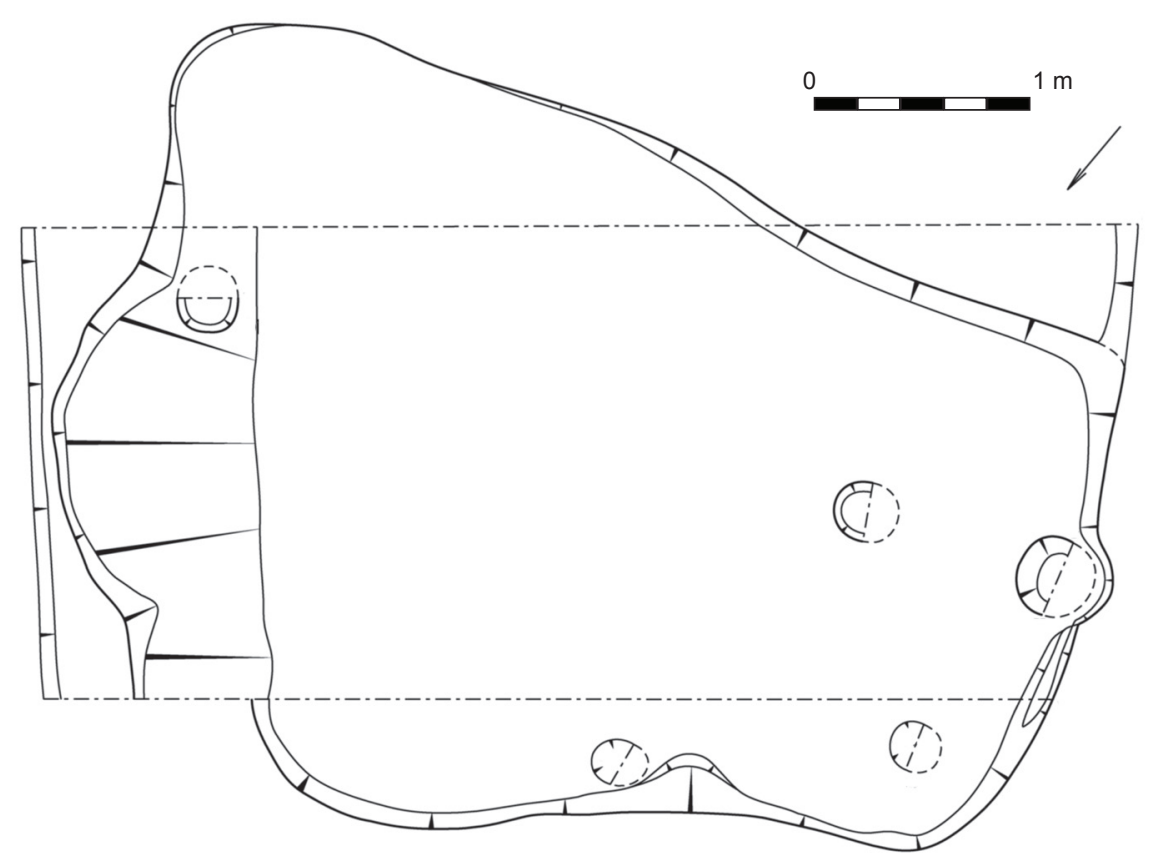

Figure 2. Floor plan of the object 521 and 538.

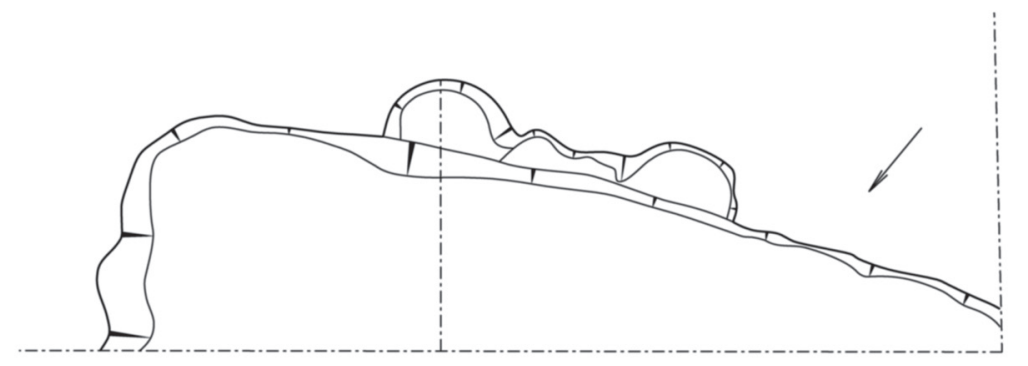

were dated to the transition between older and younger part of Roman period. The cultural layer was therefore thought to be accumulated mainly during the Roman period. Five typical Roman period sunken houses were identified in the middle of the excavated area (feature nr. 500, 544, 545, 568, 570) along with a number of typical rounded settlement pits, including concentrations of small pitholes.

In total three larger La Tène sunken features $(521,537$, 562) were documented within the site. Two of them were described as typical sunken houses; the third was only partially documented and is probably part of a common pit of irregular shape. Typical sunken house features were documented in feature 521 (Figure 2) and were also be partially observed in the second house (feature nr. 537). The sporadically visible rectangular floor plan and flat bottom are typical features of sunken houses, according to our generally used classification system. The triplet of postholes situated along the longitudinal axis of the house (feature nr. 542, $608,609)$ corresponds, according to Meduna (1980), to the A2a type of sunken house. Those types of sunken houses were supposed to have load bearing construction along the longitudinal axis. Sunken house (feature nr. 521) covers an area of $13.7 \mathrm{~m}^{2}$. With a depth of $0.6 \mathrm{~m}$ this means that the volume of the house is approximately $8.2 \mathrm{~m}^{3}$. If we also take into account that cultural layer which was very difficult to divide from the original infill of the house, than the maximal depth of the sunken house would be 1 metre and the approximate volume of the house $13.7 \mathrm{~m}^{3}$. The remains of heating facilities were not documented but a remarkable feature is the burned layer situated right on the floor layers of the house (layers 150, 154, Figure 2). The material of the burned layer was also founded within the infill of the postholes. Larger remains of burned wooden structures were not documented within those postholes.

The second sunken house (feature nr. 537, Figure 2 and 3) was not excavated in full, but the flat floor and excavated corner features were very significant parts of the sunken house. The orientation of house 537 is identical to house 521 . They are in close proximity, approximately 5 to $6 \mathrm{~m}$ apart.

The Roman period objects were more abundant. A typical sunken house had a flat solid surface with a sharp transition to the background loess. The infill was composed of gray loose silty material, easily distinguishable from the soil cover above. The depth of the Roman period sunken houses was approximately $1.2 \mathrm{~m}$ and the construction features of the house included four postholes. 


\section{object 521}
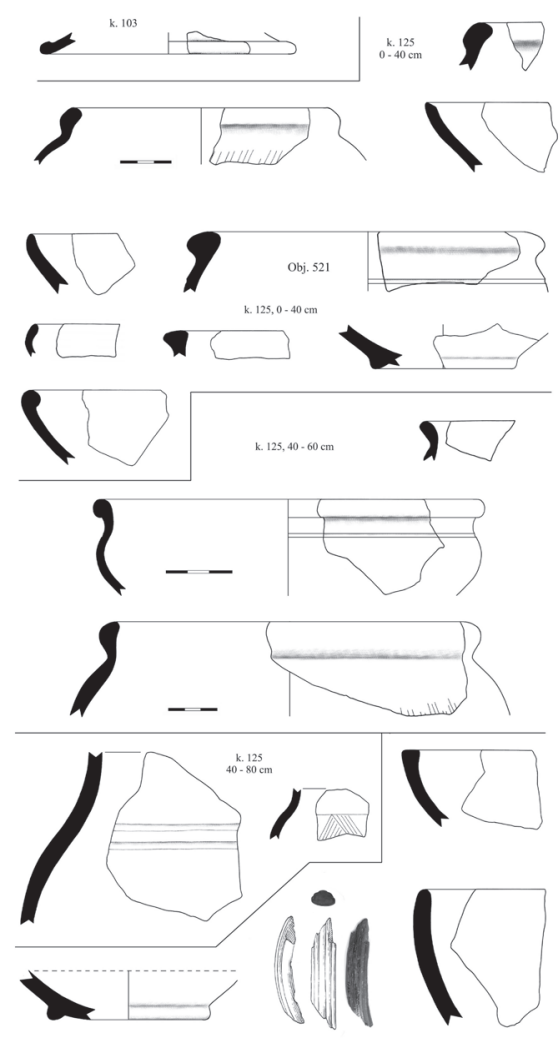

Figure 3. Ceramic finds from the object 521 and 537.

\subsection{Ceramic finds from the infill of La Tène sunken houses}

Sunken house 521 (Figure 2) was very rich with archaeological finds. Due to the complicated development of the house infill the finds were divided into two main groups according to their position in the infill. Most of the finds and well dated artefacts came from layers 125 and 156, above the burned layer. Finds below the burned layer are very rare (just 9 sherds) and compose only 3 percentages of finds. Due to the small number of artefacts and lack of identifying features, classification was impossible. The best datable material came from the upper part of the layer 125 (Figures 3 and 4). There the fragment of an LT C1 type ribbed bracelet made of sapropelite was found; similar findings were described by Venclová $(2001,100,114)$. The 330 sherds found within the infill of object 521 weighs 10,751 grams, which means that the average artefact density within the maximal house capacity is 24 pieces, or 785 grams, per $\mathrm{m}^{3}$. These included 40 lip sherds $(12.12 \%), 25$ vessel bottoms $(7.58 \%)$, and 264 body sherds $(80 \%)$. One vessel was reconstructed. Finally, 73 pieces of daub with a total weight of 1914 grams was identified. Construction features are very rarely preserved and usually lack identifying features. Angular amorphous pieces of daub are the prevalent find. Some pieces of cut wood, averaging $15 \mathrm{~mm}$ in diameter were found. A few pieces of daub have flat, coarse and raw surfaces, in one case the daub was interpreted as part of a heating feature.
Finds from the infill of sunken house 537, (Figures 2 and 4) are very rare (Figure 3). Precise dating was not possible, other than to ascribe the material generally to the La Tène period. The excavated part of the house represents approximately just $1 / 4^{\text {th }}$ of the full presumed extent of the house. The surface is $3.3 \mathrm{~m}^{2}$ and the maximal house capacity $2.64 \mathrm{~m}^{3}$. The 27 ceramic sherds weighed 445 grams resulting in a density of 10.2 sherds or 168.6 grams per $\mathrm{m}^{3}$. Compared to sunken house 521 the finds density of house 537 is much lower. This difference between two houses with the same orientation does not seems to be accidental and was repeatedly confirmed by Salač et al. (2006) in the north-west part of the Czech Republic.

\subsection{Sedimentary description of the infill of the La Tène sunken houses}

The sedimentary infill of sunken house 521 (Figures 2 and 4) was completely preserved, and reached a depth approximately 0.9-1 m. The uppermost part of the infill (layer 125, Figure 4), was quite homogenous and not distinguishable from the pedogenetically influenced cultural layer above. The structure of the layer below (156, Figure 4) was loose and contained a critical portion of the ceramic finds. Between those two layers a non-continuous dense layers of ashy loesslike material was observed (layer 157, Figure 4). Below the layer abundant finds were recorded in an orange layer (150, 


\section{1 object}

A
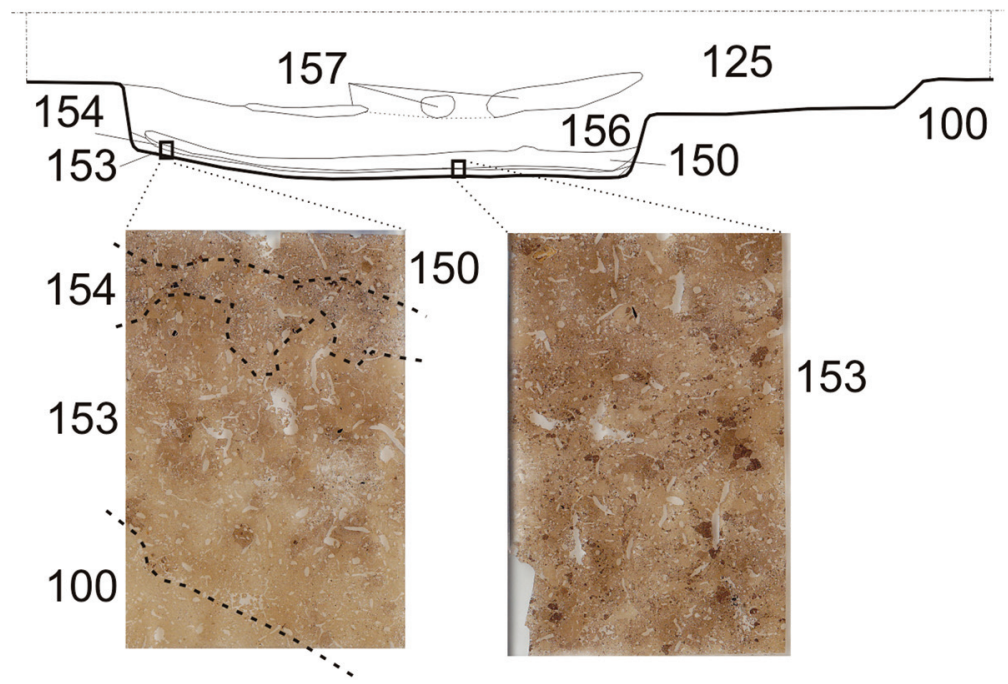

B

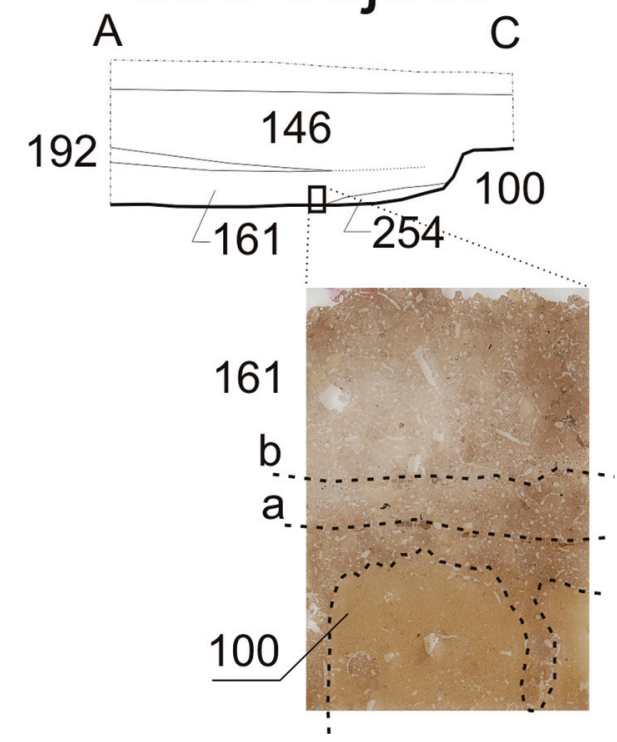

Figure 4. A short description of layers divided within the La Tène_features nr. 521 and 538: 100 - background composed of calcareous silts - loess; 125 - dark grey silty loam with charcoal, rich of artefacts; 146 - dark brown to grey slightly dense silty loam with common charcoal, upper part of this layer pedogenetically influenced; 150 - silty layer of badly sorted material with gray and orange colour; 154 - blackish, silty loam rich of microcharcoal; 155 light brown silty loam with lenses composed of loess material and thin non continuous laminas of dark brown loam; 156 - dark grey silty loam, ashy, rich of charcoal and microcharcoal; 157 - dark grey to yellow silty loam composed of redeposited loess; 161 - dark brown to grey silty loam rich of charcoal; 192 - yellow to light brown silty loam with fragments of dark brown soil; 254 - yellow to light brown silty loam with layers of redeposited loess.

Figure 4) with an ashy structure and charcoal pieces. A very thin layer of microcharcoal (layer 154) was identified on the bottom of this layer. Below it a macroscopically different lamellar horizon (layer 153, Figure 4) was identified.

Sedimentary infill of the sunken house (feature nr. 537, Figures 2 and 4) was completely preserved and extended to a depth of approximately $0.9-1 \mathrm{~m}$. The homogenous infill of object 537 has two main layers (146 and 161) composed of dark grey to brown silt with charcoal and micro-charcoal. The uppermost layer of the house infill differs from the lower infill having a higher density and less charcoal. It was difficult to precisely distinguish layer 146 from the cultural layer above. Layers 146 and 161 are divided by a layer (192, Figure 4) of redeposited loess and soil in the middle of the infill. Lenses of redeposited loess and soil were observed at the entrance the house (layer 254; Figure 4).

\subsection{Micromorphology of the infill of the La Tène sunken houses}

Macroscopically the La Tène sunken houses evidence very different infill, micro-morphologically however they are quite similar (Tab.1). Within the two studied objects, six types of micro-stratigraphical contexts are in evidence. The background loess material has the grain size and features typical of loess (i.e. the intergrain vesicular pore structure has no dominant orientation, simple packing and compound packing voids and vesicles are abundant, loamy grain size, porphyric or loose porphyric $\mathrm{C} / \mathrm{F}$ distribution, pale brown colour and crystallitic B-fabric). The most typical pedogenic features were calcium carbonate concentrations. The microstratigraphy of sunken house 537 is not disturbed as much as house marked 521 where just two microstratigraphic contexts are found within the lower part of the infill (Table 1). The prevalent material is characterised by massive to intergrain vesicular microstructures with no dominant orientation. The most typical voids observed are vesicles and channels. The grain size is clay loam with loose porphyric $\mathrm{C} / \mathrm{F}$ distribution, pale brown to ochre brown colour and crystallic B-fabric. Typical pedofeatures are carbonate concentrations, coating and charcoal (Table 1). Within this layer at least two very thin $(0.1 \mathrm{~mm})$ dark brown layers were observed. The microstratigraphy of this layer is very similar to the main type of the infill except for the colour, higher abundance of decomposed organic opaque matter, the presence of bone fragments and stipple speckled B-fabric. Very similar horizons were observed as bioturbated angular-shaped remains within the horizon 155 of sunken house 521 .

The infill of sunken house 521 is highly bioturbated. Three micro-stratigraphic contexts plus the loess background were identified. The lowermost (155) contains bioturbated loess material and fragments of thin humic layers already observed in house 537. The microstructure of this layer is an intergrain vesicular pore structure, with the dominant orientation observed just within the thin humic layers. The grain size is loamy with porphyric $\mathrm{C} / \mathrm{F}$ distribution and single packing prevalent, compound packing voids, vesicles, 


\begin{tabular}{|c|c|c|c|c|c|c|c|c|c|}
\hline \multirow{4}{*}{ 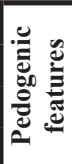 } & รұนวшә.юх & & & $\bullet \bullet \bullet \bullet$ & $\bullet \bullet \bullet \bullet$ & & & & \\
\hline & ธิน!ฺยоว & & $\bullet$ & $\bullet$ & $\bullet$ & $\bullet \bullet \bullet$ & $\bullet \bullet \bullet$ & & \\
\hline & 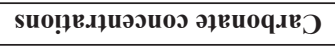 & $\bullet \bullet \bullet$ & $\bullet \bullet \bullet$ & $\bullet \bullet$ & $\bullet \bullet$ & $\bullet \bullet \bullet \bullet$ & $\bullet \bullet$ & $\bullet \bullet \bullet$ & $\bullet \bullet \bullet \bullet \bullet$ \\
\hline & sojnpou snoydsouv & & & $\bullet$ & $\bullet$ & & & & \\
\hline \multirow{3}{*}{ 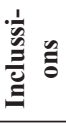 } & qned & & & $\bullet \bullet$ & $\bullet \bullet \bullet$ & & & & \\
\hline & səuog & & $\bullet \bullet$ & $\bullet \bullet$ & $\bullet \bullet \bullet$ & & $\bullet \bullet$ & & \\
\hline & [воэ.вЧว & & $\bullet \bullet$ & $\bullet \bullet \bullet \bullet \bullet \bullet \bullet$ & $\bullet \bullet \bullet$ & - & $\bullet$ & & \\
\hline \multirow{4}{*}{ 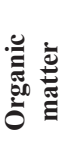 } & su!̣enłound & $\bullet \bullet$ & $\bullet \bullet$ & & & $\bullet$ & $\bullet$ & $\bullet \bullet$ & $\bullet \bullet \bullet \bullet$ \\
\hline & 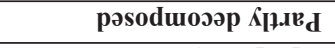 & & $\bullet \bullet$ & $\bullet \bullet$ & $\bullet \bullet$ & $\bullet$ & $\bullet \bullet$ & $\bullet \bullet$ & $\bullet \bullet \bullet \bullet \bullet$ \\
\hline & 14oิ!! วnbedo & $\bullet \bullet$ & $\bullet \bullet$ & $\bullet \bullet \bullet \bullet \bullet$ & 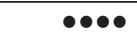 & $\bullet$ & $\bullet \bullet$ & $\bullet \bullet$ & \\
\hline & צ'Irp әnbedo & $\bullet \bullet$ & $\bullet \bullet$ & $\bullet$ & $\bullet \bullet$ & $\bullet \bullet$ & $\bullet \bullet \bullet \bullet$ & $\bullet \bullet$ & $\bullet \bullet \bullet$ \\
\hline \multirow{3}{*}{ 离 } & SI!SSOH $_{\text {H }}$ & $\bullet$ & $\bullet$ & & & $\bullet$ & $\bullet$ & & $\bullet$ \\
\hline & Sәฺ'[8xO & & & $\bullet \bullet \bullet$ & $\bullet \bullet \bullet$ & & & & $\bullet \bullet$ \\
\hline & sप!!!0ұКपd & & $\bullet \bullet \bullet$ & $\bullet \bullet \bullet \bullet$ & $\bullet \bullet \bullet \bullet$ & $\bullet$ & $\bullet \bullet$ & & $\bullet \bullet \bullet \bullet \bullet$ \\
\hline \multirow{5}{*}{ 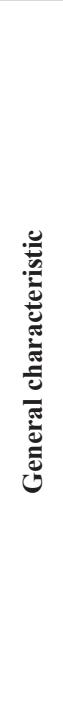 } & ग!ฺqвJ-g & 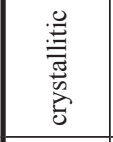 & 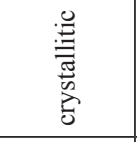 & 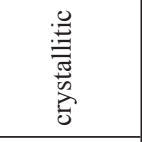 & 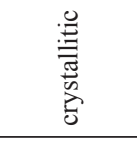 & 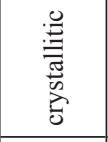 & 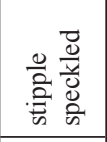 & 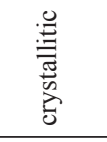 & 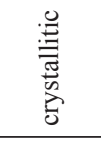 \\
\hline & 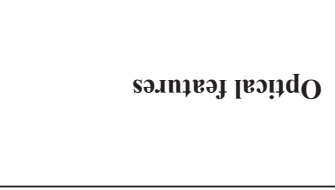 & 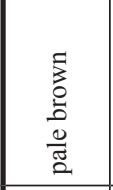 & 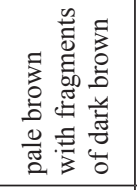 & 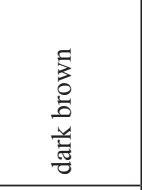 & 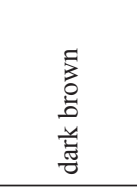 & 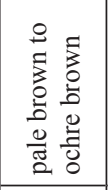 & 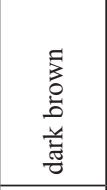 & 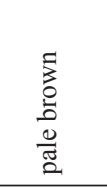 & $\begin{array}{l}5 \\
0 \\
0\end{array}$ \\
\hline & uo!̣nq!.!s!p J/ว & 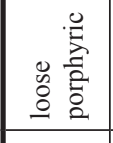 & $\begin{array}{l}\stackrel{0}{2} \\
\text { 总 } \\
\text { : }\end{array}$ & 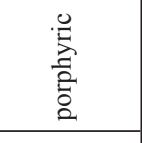 & 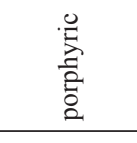 & $\begin{array}{l}\stackrel{0}{2} \\
\text { 范 } \\
\text { : }\end{array}$ & 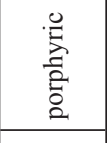 & 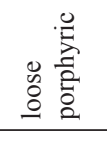 & 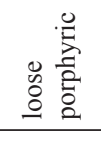 \\
\hline & (ufu) $\mathbf{y} / \mathrm{P}$ & 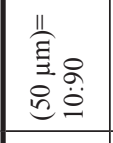 & 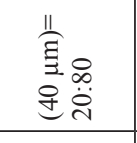 & 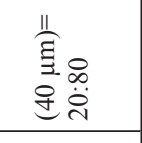 & $\begin{array}{l}\text { 恶。 } \\
\text { 导 } \\
\dot{\tilde{N}}\end{array}$ & $\begin{array}{l}\text { 量。 } \\
\text { 导宅 }\end{array}$ & $\begin{array}{l}\text { 吾。 } \\
\text { 足总 }\end{array}$ & 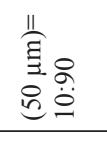 & 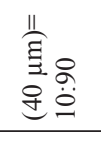 \\
\hline & uo!̣!soduos әZ!̣s u!̣.ID & 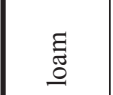 & ణ్ & 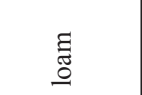 & ణ్ & 㞼志 & 丞 志 & ฮ్ & 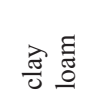 \\
\hline \multirow{7}{*}{ 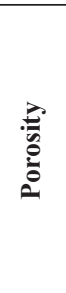 } & $\operatorname{syosn}_{\Lambda}$ & $\bullet \bullet$ & $\bullet \bullet \bullet$ & & $\bullet$ & & & $\bullet \bullet$ & \\
\hline & SYวE.Xว & & $\bullet$ & & & & $\bullet$ & & \\
\hline & sјәичечว & & $\bullet \bullet$ & $\bullet \bullet \bullet \bullet$ & $\bullet \bullet \bullet \bullet$ & $\bullet$ & & & $\bullet \bullet \bullet$ \\
\hline & 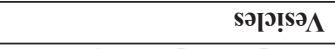 & $\bullet \bullet \bullet \bullet$ & $\bullet \bullet \bullet \bullet$ & $\bullet \bullet$ & $\bullet \bullet$ & $\bullet \bullet$ & $\bullet$ & $\bullet \bullet \bullet$ & $\bullet \bullet \bullet$ \\
\hline & sిu!yjed punoduoว & $\bullet \bullet \bullet \bullet$ & $\bullet \bullet \bullet \bullet$ & $\bullet \bullet \bullet \bullet$ & $\bullet \bullet \bullet \bullet$ & & & $\bullet \bullet \bullet \bullet$ & $\bullet \bullet \bullet \bullet$ \\
\hline & 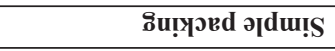 & 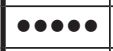 & 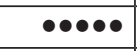 & $\bullet \bullet \bullet \bullet \bullet \bullet \bullet$ & $\bullet \bullet \bullet \bullet \bullet \bullet \bullet$ & $\bullet$ & $\bullet$ & $\bullet \bullet \bullet \bullet \bullet \bullet$ & $\bullet \bullet \bullet$ \\
\hline & sourld & & $\bullet$ & & & & $\bullet$ & & \\
\hline \multirow{2}{*}{ 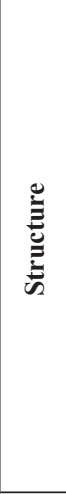 } & 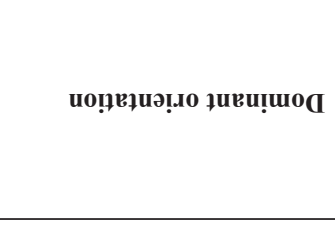 & $\stackrel{\Xi}{\Xi}$ & 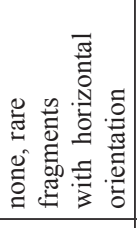 & ๕ & 气 & $\stackrel{0}{\Xi}$ & 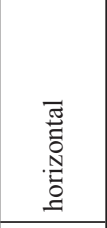 & $\stackrel{\Xi}{\Xi}$ & $\stackrel{\Xi}{\Xi}$ \\
\hline & 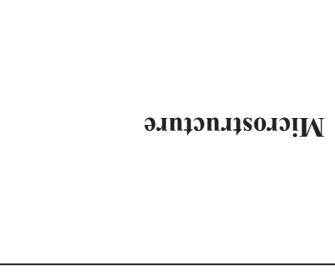 & 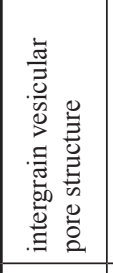 & 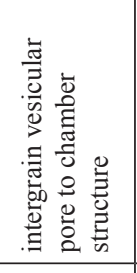 & 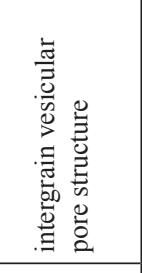 & 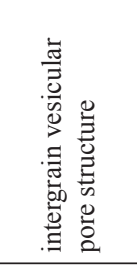 & 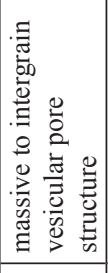 & 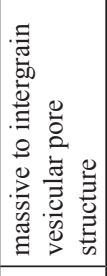 & 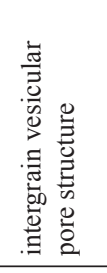 & 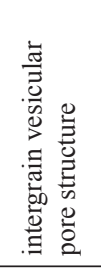 \\
\hline & 蓠 & 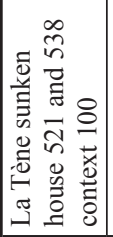 & 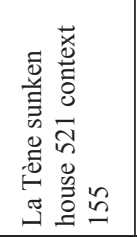 & 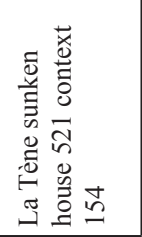 & 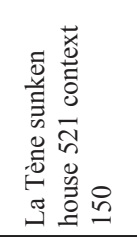 & 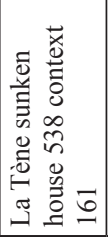 & 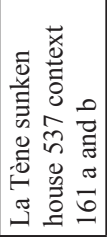 & 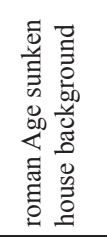 & 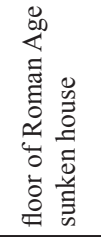 \\
\hline
\end{tabular}


chambers and channels. The prevailing colour is pale brown with fragments of dark brown and crystallitic B-fabric rich with partially decomposed organic matter, microcharcoal, phytoliths and bone fragments. Above this layer is situated a dark brow porphyric loam with crystallitic B-fabric. Within this loam are found contexts 154 and 150. These layers are quite similar to each other, though 154 has a greater degree of bioturbation, charcoal and more burned daub, while more charcoal has accumulated within 150. Layers 154 and 150 are characterised by an intergrain vesicular pore structure with a high abundance of compound packing and single packing voids. Channels and vesicles are also quite common due to the degree of bioturbation. The grain size of these layes is loam with a porphyric $\mathrm{C} / \mathrm{F}$ distribution (Table 1), dark brown colour and crystallitic B-fabric. Due to the presence of phytolith and calcium oxalate accumulations, pedogenic features are interpreted as excrement Charcoal and burned pieces of daub were observed within this layer, and form the main evidence of the destruction of this sunken house.

\subsection{Micromorphology of the Roman Period floor layer}

The microstratigraphy of the Roman Period sunken house (feature nr. 544) floor layer evidences a very different type of the floor maintenance and preservation. There are just two micromorphological contexts including the background loess. The loess microstructure was already described in the context of the La Tène sunken houses infill (Table 1). The floor layer, situated with a sharp upper transition is characterised by an intergrain vesicular pore microstructure. The grain size was described as a clay loam with a loose porphyric $\mathrm{C} / \mathrm{F}$ distribution, brown colour, crystallitic B-fabric and simple packing, compound packing voids, vesicles and channels within the groundmass. The presence of the high number of phytoliths, partly decomposed organic matter and accumulations of carbonate concentrations fits with type. Calcium oxalates were also identified.

5.6 Phytolith analyses from the Roman Period floor layer The spectrum of phytoliths is relatively simple and uniform. 400 phytoliths were randomly selected for statistical analysis. An elongate, densely connected, type without texture predominates $(80 \%)$. Less common are elongated with sinuate texture (about 5\%). An elongate type with dendritic texture (less than $2 \%$ ) is very rare. Tracheid types with sulcate texture were also rarely observed.

\section{Discussion}

6.1 The information value of the archaeological features Due to the fact that the excavated site was just $10 \mathrm{~m}$ wide, the possibilities for general interpretations are quite restricted. The La Tène sunken houses do not differ significantly from other, non-fortified lowland settlement agglomerations. Also the type and the density of such sites are very similar to the ones found here at Syrovice. Interpretations concerning the settlement or its general context cannot be made at this time due to the insufficient excavation area. In spite of this, attention should be paid to doubles of the sunken houses with the same orientation. Similar doubles are repeatedly reported from common lowland settlements within Moravia (Čižmář 2003, and unpublished excavations at Medlovice) and also from Bohemia.

The initial interpretation of the appearance of La Tène sunken double houses was conducted by Salač et al. (2006). He reports the random appearance of these double houses at Březno, Břešt’any and Radovesice. At Břešt’any and Radovesice they were interpreted as a product of the reconstruction of single houses within individual settlements. One house was always found with an artefact rich infill, while the other was artefact poor. Those rich in artefacts are interpreted as houses intentionally destroyed during the occupation of the settlement, while those with a paucity of artefacts are thought to have been inhabited up to the settlements final stages. After the abandonment of the site, those houses were destroyed and their depressions filled in naturally (Salač et al. 2006).

\subsection{The information value of the ceramic finds}

A rich find of ceramic artefacts was reported from the infill of object 521 (Parma 2011). Most come from uppermost layers 125 and 156 (Figure 3) which aggregated post-occupation, and reflect the environment of the area around the house, a circumstance common to archaeological contexts (Vencl 2001) from different time periods. Finds therefore reflect, first of all, a wider interval in the settlement occupation within the generally accepted archaeological chronology. In this case the LT C period lasted more than hundred years. Archaeological dating, by ceramic chronology, will probably not be any more precise in future. Details of the manner in which the infill aggregated could be reconstructed by a very precise locating of finds by sampling in $5 \mathrm{~cm}$ intervals (Ernee 2008). However, this method is very difficult in rescue research and was not fully applied in research conducted at Syrovice (Parma 2011).

\subsection{The information value of sedimentary infill}

The sedimentary infill examined gives us quite a good picture of the way the objects were built, used and destroyed over time. The infill of house 537 seemed quite homogenous and served as a very important key for the recognition of floor layers within the studied La Tène houses. Generally the infill was a soil horizon rich in charcoal, but with few ceramic finds, formed by the natural redeposition of the infill together with the soil matrix. The floor layer was found preserved nearly continuously across the infill in spite of the fact it was not possible to recognise it macroscopically. It is characterised by a $0.1 \mathrm{~mm}$ thin layer with higher compaction, rich in decomposed, very fine grained, organic matter and anthropogenic features like charcoal, phytoliths from organic matter intentionally deposited by humans, and occasional bone fragments. Excremental features, or the remains of stabling, were not recognised and the layer was interpreted as a beaten floor. The floor horizon is composed of two thin 
layers of beaten floor, which suggests that the house lasted for a relatively short period.

Thanks to the appearance of the in situ beaten floor within object 537 it was possible to track the provenance of the highly bioturbated angular fragments within the lower part of the infill of house 521. Those angular fragments are similar in structure and composition and thought to be the remains of beaten floors. In spite of the fact this layer is recognisable only through bioturbated fragments, it can be posited that the object did not functioned as a stabling area. Macphail et al. (2004) described preserved stabling in Pimperne house in Butzer as a massive layer that comprised a mat (monocotyledonous fibres). Such features were not observed in Syrovice La Tène houses at all. Those floor layers suggest some kind of maintenance, that is, their appearance suggests the beaten floor of a domestic house. Beaten floors reported by Macphail et al. (2004) from the burned Moel-y-gar house in the Butzer experimental project would be much more mineralogenic and heterogeneous in terms of their microfabric, which corresponds to the Syrovice sunken house floor layers. Cammas (1994) reported beaten floors from Lattes (France) as a compacted, disaggregated substrate with integrated anthropogenic components. Within floor layers at Syrovice bones fragments, charcoal and a humic rich matrix were found, which suggests a beaten floor origin. The thickness of beaten floor layers is approximately $0.1 \mathrm{~mm}$ and they appear repeatedly, which implies a longer utilisation. The layer of burned daub and charcoal suggests the destruction of the house by fire. The same type of material was reported from the infill of the postholes, which suggests that the house was burned down purposely, after some crucial structural features had been removed. This seems to be a practical and a quick way to destroy an old building (Macphail et al. 2004). Macphail (2003) describes analogical post-sedimentary processes preserved in microstratigraphic record from Moel-y-gar in Butzer.

The destruction layer of house 521 is also rich with an unburned humic matrix and excrement accumulations. This suggests that post-destruction the object served as a dump for some time. In the same period, ceramic fragments deposited into the object depression, formed layer 156. The presence of excrement provides a reason for increased bioturbation which was also sometimes visible macroscopically.

The Roman period floor in feature nr. 544 provides a useful comparison of how a floor can be preserved. During excavation the floor was found to be harder and more compact, and therefore readily recognisable macroscopically. Micromorphologically the floor layer is composed of a humic rich matrix, with numerous phytoliths, but almost no calcium oxalates. This layer was interpreted as a typical beaten floor. Elongated phytoliths from all plant families are wide spread. The absence of other types likes hair cells, globular or trichome bases, can be interpreted as the presence of a plant mass, mainly from grasses. We can exclude cereals, due to the absence of their specific phytoliths types (Ball et al. 1996), even though they are quite common in archaeological situations. Therefore it is possible that the floor was likely covered only by hay. Due to the absence of the charcoal accumulation it is possible to suggest some kind of floor maintenance, even though a preferred orientation of clasts was not observed.

\subsection{Hypotheses of the infill aggregation in connection of the object history}

The basic quantitative characteristics of the objects examined are comparable to other analogous La Tène sunken houses. In spite of the fact that analogical data from Moravia do not exist, we can use data from the north west Bohemia for the purposes of comparison (Salač 1998). A very good comparative study can be conducted for general values and the weight of ceramic sherds. The standard of artefact finds from sunken house infill is defined by Salač (1998) as 388 pieces and $12.3 \mathrm{~kg}$ per object. The values from our contexts at Syrovice are just slightly lower. A comparison can also be made of the presence of edge sherds and sherds of vessel bottoms. Salač defined approximately $11.7 \%$ for the first and $7.6 \%$ for the second. A lower correlation was found with artefact density and artefact weight density. The standard defined by Salač (1998) is 68.6 pieces and $2.2 \mathrm{~kg}$ per the square meter. This discrepancy could be interpreted as a result of different excavation methods. Salač counted artefacts only from the object itself because he was able to quite precisely distinguish the infill from the cultural layer above. In the excavation at Syrovice the infill of the objects was considered to also include part of the indistinguishable cultural layer above, which contains a very low number of artefacts.

Salač et al. (2006) hypothesized about the infill aggregations and origins of ceramic accumulations found at the La Tène sunken houses in northwest Bohemia. The first hypotheses considers intentional post-habitation infilling, with rubbish. In this instance ceramic finds should be characterised generally by undestroyed ceramic sherds from which more or less whole vessels can be reconstructed. According to Neustupný (2007) this type of infill is a secondary depot. Another possibility is infill with high concentrations of subangular sherds arriving with the repeated and intentional deposition of rubbish from the surface of the settlement. In this case the infill is interpreted as a tertiary deposit, $i$. $e$. the deposit arrives from the former deposition area (from a stable for example) (Neústupný, 2007).

The second Salač hypothesis (2006), or hypothesis of chaos, assumes that unused vessels were chaotically distributed within the settlement and slowly decayed by different exogenous processes. When the settlement was abandoned, sherds were naturally redeposited into depression traps formed by unused and decaying sunken house. This hypothesis is based on the absence of whole vessels or their primary parts and on the quite uniform quantitative character of the sherds commonly found. The different density of the ceramic finds in sunken objects could point to different ways, or the different intensity with which an area was exploited.

To test these hypotheses seems difficult in the absence of the data required for quantification, as can be seen in the manner interpretations are very generally formulated (Salač 
et al. 2006). Ceramic finds from Syrovice will not shine much light on the problem. In spite of this it is obvious that the basic characteristics of our contexts do not correspond well to the sharply formulated model of Salač (1998). Small sherds which can not be wholly, or partially, reconstructed are prevalent at the Syrovice La Tène sunken houses, which suggests tertiary deposition. On the other hand the presence of larger sherds (Fig. 3) can be interpreted as secondary depositions. Therefore this site can be interpreted as a mix of tertiary and secondary deposits.

\section{Conclusions}

La Tène sunken houses excavated at Syrovice do not differ significantly from other, non-fortified, lowland settlement agglomerations in Moravia or Bohemia. The type and density of finds is also very similar to other known La Tène settlements. The most interesting type of archaeological feature is the La Tène sunken double-house which differs significantly for the informative value of its infill and finds. The later stage of settlement is reflected in the infill of sunken house 521, whose occupation period is identifiable from fragments within the highly bioturbated, humic-rich, floor layers, interpreted as beaten floors. The house was later burned down, used as a dump, and then rebuilt a few meters away with the same orientation. The new house was used for a relatively short period, as suggested by the single significant layer of beaten floor. After the settlement was abandoned the house naturally decomposed and was filled in by the surrounding humic-rich material. The Roman period sunken house floor layers were much better preserved, and composed of phytolith accumulations which suggested the intentional deposition of dry hay on the floor during habitation.

\section{References}

BALL, T., GARDNER, J. S., BROTHERSON, J. D. 1996: Identifying Phytoliths Produced by the Inflorescence Bracts of Three Species of Wheat (Triticum monococcum L., T. dicoccon Schrank. and T. aktivum L.). Using Computer-Assisted Image and Statistical analyse, Journal of Archaeological Science, 23, 4, 619-632.

BELCREDI, L., ČIŽMÁŘ, M., KOŠŤUŘíK, P., OLIVA, M., SALAŠ, M. 1989: Archeologické lokality a nálezy okresu Brno-venkov. Brno.

BOIVIN, N. 2000: Life rhytms and life sequences: Excavating time in rural Rajasthan and Neolithic Catalhőyük, World Archaeology, 31 (3), 367-388.

BULLOCK, P., MURPHY, C. P. (eds.) 1983: Soil micromorphology. AB Academic, Berkhamsted.

BULLOU, P., FEDOROFF, N., JONGERIUS, A., STOOPS, G., TURSINA, T. 1985: Handbook for soil thin section description. Waine Research Publications, Wolverhamton.

CAMMAS, C. 1994: Approche micromorphologique de la stratigrafie urbaine à Lattes: premiers résultats, Lattara 7, A. R. A. L. O, Lattes, $181-202$

COURTY, M. A., Goldberg, P., Macphail, R. 1989: Soil and micromorphology in archeology. Cambridge, University Press, New York.

ČIŽMÁř, M. 2003: Laténské sídliště v Bořitově. Pravěk, Supplementum 10, Brno.
ERNÉE, M. 2008: Pravěké kulturní souvrství jako archeologický pramen. Památky archeologické, Supplementum 20. Praha.

FRENCH, C. (2003): Geoarchaeology in action: studies in soil micromorphology and landscape evolution. Routledge, London.

GOLDBERG, P., HOLLIDAY, H., FERRING C. R. (eds.) 2001: Earth science and archeology. Kluwer Academic/Plenum Publishers, New York.

GOLDBERG, P., MACPHAIL, R. 2006: Practical and theoretical geoarchaeology. Blackwell Publishing, Malden, Oxford, Victoria.

JAROŠOVÁ, M., LISÁ, L., PŘICHYSTAL, A., PARMA, D., PETR, L., KOS, P. 2010: Geoarcheologický výzkum halštatské zemnice v Modřicích u Brna, Výzkumy na Moravě a ve Slezsku, 39-45.

KARKANAS, P., EFSTRATIOU, N. 2009: Floor sequences in Neolithic Macri, Greece: Micromorphology reveal cycles of renovation, Antiquity, 83, 955-967.

LENTFER, C. J., BOYD, W. E. 1998: A Comparison of Three Methods for the Extraciton of Phytoliths from Sediments, Journal of Archaeological Science, 25, 12, 1159-1183.

LISÁ, L., BURIÁNEK, D., UHER, P. 2005: Provenance of Würm, Late Pleistocene Loess and Loess-like Sediments from Moravia and Silesia, Czech Republic, use of heavy mineral assembladges, Acta Mus. Moraviae, Sci. Geol., XC (2005), 147-154.

LISÁ, L., PEŠKA, M., MERTA, D., BAJER, A., ZŮBEK, A. 2007: Aplikace geoarcheologie při interpretaci pleistocenních and holocenních sedimentů v prostoru Náměstí Svobody v Brně, Ve službách archeologie, $1,177-181$

LISÁ, L., KOLAŘÍK, V., BAJER, A. 2008: The geoarchaeological and micromorphological reconstruction of medieval food store room floor layers; the case study from Tišnov, Czech Republic, Frankfurter Geowissenschaftliche Arbeiten. Serie D, Band 30, Archaeological Soil Micromorphology - Contributions to the Archaeological Soil Micromorphology Working Group Meeting 3rd to 5th April 2008. 6775.

MACHÁČEK, J. 2001: Studie k velkomoravské keramice. Metody, analýzy a syntézy, modely. Masarykova univerzita, Brno.

MACPHAIL, R. I., LUISE, G. M. 2001: The soil micromorphologist as a team player: A multianalytical approach to the study of European microstratigraphy. In. P. Goldberg, V. Holliday, C. R. Ferring (Eds.): Earth science and archeology. Kluwer Academic/Plenum Publishers, New York.

MACPHAIL, R., I., CRUISE, G., M., ALLEN, M., J., LINDERHOLM, J., REYNOLDS, P. 2004: Archaeological soil and pollen analysis of experimental floor deposits; with special reference to Butser Ancient Farm, Hampsire, UK, Journal of Archaeological Science, 31, 175-191.

MADELLA, M., ALEXANDRE, A., BALL, T. 2005: International Code for Phytolith nomenclature 1.0, Annals of Botany, 96, 253-260.

MATTHEWS, W., FRENCH, C. A. I., LAWRENCE, T., CUTLER, D. F., JONES, M. J. 1997: Microstratigraphic traces of site formation processes and human activities, World Archaeology, 29 (2), 281-308.

MEDUNA, J. 1980: Die latènezeilichen Siedlungen in Mähren. Praha.

MILEK, K. 1997: Micromorphology and the Medieval Urban Environment, Examples from Ely and Peterborough, Cambridgeshire, England. In: Environment and Subsistence in Medieval Europe. Papers of the „,Medieval Europe Brugge 1997“ Conference. Volume 09.

MUCHY, C. P. 1986: Thin section preparation of soils and sediments. A.B. Academic Publishers, Berkhamsted.

NEUSTUPNÝ, E. 2007: Metoda archeologie. Plzeň.

PARMA, D. 2011: Laténské sídliště z katastru obce Syrovice (okr. Brnovenkov), Pravěk NǨ, 19, 161-183.

PIPERNO, D. R. 2006: Phytoliths: A Comprehensive Guide for Archaeologists and Paleoecologists. AltaMira Press.

RYBOVÁ, A., DRDA, P. 1994: Hradiště by Stradonice. Rebirth of the celtic oppidum. Praha.

ŠABATOVÁ, K., VITULA, P. 2002: Přáslavice. Díly pod dědinou, Kousky a kukličky (II). Pohřebiště a sidliště z doby bronzové (catalogue). Archaeologiae Regionalis Fontes 4, Olomouc.

SALAČ, V. 1993: Sz. Čechy v posledních staletích starého letopočtu. Unpublished thesis. Praha, Vadín.

SALAČ, V. 1995: The density of archeaological finds in settlement features of the La Tène period. In: M. Kuna, N. Venclová (eds.): Wither Archaeology? Papers in honour of Evžen Neustupný, 264-276. Praha. 
SALAČ, V. 1998: Standardní soubor laténské sídlištní keramiky, Archeologické rozhledy 50, 43-94.

SALAČ, V., NERUDA, R., KUBÁLEK, T. 2006: Sídliště z doby laténské a řimské v Březně u Chomutova. Kvantitativní vlastnosti keramických soubori. Praha.

SIEVERS, S. 2000: Vrobericht über die Ausgrabungen 1998-1999 im Oppidum von Manching, Germania 78. 355-394.

STOOPS, G., MARCELINO, V., MEES, F. 2010: Interpretation of micromorphological features of soils and regoliths. Elsevier, Amsterdam.

STOOPS, G. (ed.) 2003: Guidelines for Analysis ond Description of Soil and Regolith Thin Sections. Soil Science Society of America, Inc., Medison.
TICHÝ, R., DOHNÁLKOVÁ, H., LISÁ L. 2011: Odpadní jámy nebo blátivé louže?, Živá archeologie 11/2010.

VENCL, S. 2001: Souvislosti chápání pojmu „nálezový celek“ v české archeologii, Archeologické rozhledy 53, 592-614.

VENCLOVÁ, N. 2001: Výroba a sidla v době laténské. Projekt Loděnice. Praha.

VENCLOVÁ, N. (ed.) 2008: Doba laténská. Archeologie pravěkých Čech 7. Praha.

WALDHAUSER, J. 1993: Die hallstatt- und latènezeiliche Siedlung und Gräberfeld bei Radovesice in Böhmen. Praha. 
